\title{
PEMBERDAYAAN SANTRI TANGGUH DAN MASYARAKAT SEKITAR DALAM PENCEGAHAN COVID-19
}

\author{
Eko Setiawan*, Afif Tristanti, Aminatul Rizqa Oktifia, As'idatin Mu'asyaroh, Dea \\ Monica Sary, Dia Anggraini, Lutfi Indah Nurjihananingrum, Mazidatul Husna, M. Ibnu \\ Ma'ruf Effendy, Rina Maulidiyah, Septi Rahayu Maulana, Tasya Nur A. \\ Fakultas Agama Islam, Universitas Islam Malang \\ *korespondensi email: ekosetiawan@unisma.ac.id
}

\begin{abstract}
ABSTRAK
Saat ini Negara Indonesia sedang mengalami masa pandemi, dimana sedang marakmaraknya wabah Virus Corona (Covid-19). Program KSM-T ini bertujuan sebagai upaya untuk mengarahkan para Santri agar selalu menjaga kesehatan dan tetap mematuhi protokol kesehatan sebagaimana anjuran dari Pemerintah, serta bertujuan untuk menumbuhkan kesadaran masyarakat dalam menjaga kesehatan dan kebersihan diri sendiri serta lingkungan. Sekaligus meningkatkan produktfitas masyarakat ditengan pandemic Covid-19 melalui program kegiatan Sosialisasi pencegahan Covid-19, penanaman TOGA, Pembuatan Handsanitizer mandiri, dan kerja bakti membersihkan mushola. Program KSM-T ini di bagi menjadi 3 Tahapan, diantarannya: sosialisasi, penyuluhan serta pendampingan dan evaluasi. Dalam melaksanakan kegiatan ini perlu adanya kerja sama dengan pihak Pondok Pesantren dan pihak Desa selaku tuan rumah, santri dan masyarakat sekitar sebagai peserta, sehingga program KSM-T ini dapat berjalan dan berkelanjutan. Dalam kegiatan pengabdian ini dapat ditarik kesimpulan sebagai langkah antisipasi dalam pencegahan Covid-19 terhadap kesehatan ataupun kebersihan lingkungan di Pondok Pesantren dan di lingkungan masyarakat.
\end{abstract}

Kata Kunci: pemberdayaan; santri dan masyarakat; pencegahan covid-19

\section{PENDAHULUAN}

Pada saat ini Negara Indonesia sedang mengalami masa pandemi, dimana sedang marak-maraknya wabah Virus Corona (Covid-19). Virus Corona adalah penyakit atau virus jenis baru yang belum pernah diidentifikasi oleh manusia sebelumnya. Virus Corona dapat menyerang sistem pernafasan sehingga mengakibatkan penderitanya mengalami sesak nafas, pneumonia akut dan hingga berujung kematian (Ilpaj \& Nurwati, 2020; Pane, 2020; Siagian, 2020). Pandemi ini tidak hanya melanda di Negara Indonesia, akan tetapi di seluruh dunia juga merasakan adanya pandemi Virus Corona (Covid-19). Menurut (Purnamasari \& Ell Raharyani, 2020) Virus Corona (Covid-19) telah menyebar lebih dari 215 Negara di dunia termasuk di Negara Indonesia.

Di masa pandemi Covid-19 ini, masyarakat Indonesia merasakan dampaknya, mulai dari berbagai aspek seperti aspek ekonomi, aspek kesehatan, aspek pendidikan, dan aspekaspek lainnya (Jureid, 2020; Safi et al., 2021). Dengan adanya dampak ini, mengakibatkan perubahan kebiasaan masyarakat Indonesia yang sebelumnya tidak pernah dilakukan, sehingga mereka harus membuat sebuah kebiasaan baru atau biasa disebut dengan Era 
New Normal (Bahri \& Arafah, 2020; Habibi, 2020; Bahri \& Arafah, 2020; Puspa et al., 2020). Tercapainya Pemberdayaan Santri Tangguh PPSQ. Sholahul Huda dan Masyarakat dalam Pencegahan Covid-19 merupakan harapan kami selaku mahasiswa KSM-Tematik kelompok 19 yang ada di lokasi Desa Malangsuko, Kecamatan Tumpang, Kabupaten Malang, Jawa Timur.

Berdasarkan survei yang telah dilakukan oleh mahasiswa KSM-T Kelompok 19 berbasis keilmuan "Pemberdayaan Santri Tangguh PPSQ. Sholahul Huda dan Masyarakat dalam Pencegahan Covid-19" yang ada di lokasi Desa Malangsuko Kecamatan Tumpang, Kabupaten Malang. Mahasiswa menemukan keadaan para santri dan masyarakat sekitar belum bisa beradaptasi dengan keadaan yang terjadi saat ini, karena mungkin kurang adanya sosialisasi serta edukasi yang tepat mengenai pencegahan Covid-19.

Beberapa dinamika yang sedang dialami karena adanya pandemi Covid-19 antara lain, hilangnya mata pencaharian, ketahanan pangan menurun dan kesehatan ataupun kebersihan lingkungan karena adanya pembatasan sosial menjadi tidak stabil (Hirawan \& Verselita, 2020; Pratiwi et al., 2020) . Pada kesempatan kali in, kami selaku mahasiswa Universitas Islam Malang KSM-T kelompok 19 berharap para santri dan masyarakat sekitar tangguh dalam mencegah Covid-19. Dalam keadaan seperti ini, perlu adanya kesadaran, peningkatan dan peran penting pada setiap elemen masyarakat. Bersama-sama kita bisa membangun kerja sama demi tercapainya produktifitas dan ketahanan kesehatan yang cukup, agar semua dapat saling membantu serta mendukung sesama dalam pencegahan Covid-19.

Dari penjelasan diatas, maka kami menawarkan beberapa kegiatan kepada para santri melalui sosialisasi pencegahan Covid-19, pembagian masker dan menanam TOGA. Hal ini bertujuan sebagai salah satu upaya kami untuk mengarahkan para Santri agar selalu menjaga kesehatan dan tetap mematuhi protokol kesehatan sebagaimana anjuran dari Pemerintah. Disamping itu kami juga menawarkan beberapa program kepada masyarakat Desa Malangsuko antara lain, melakukan pembuatan handsanitizer bersama ibu-ibu kader desa Malangsuko dan kerja bakti membersihkan Musholla. Hal ini bertujuan untuk menumbuhkan kesadaran masyarakat dalam menjaga kesehatan dan kebersihan diri sendiri serta lingkungan. Sekaligus meningkatkan produktfitas masyarakat ditengan pandemic Covid-19.

Keluaran dari program kami nantinya dapat memberdayakan santri dan masyarakat tangguh dalam pencegahan Covid-19 di Desa Malangsuko, agar meningkatkan kesadaran dan kemandirian dalam menjaga kebersihan diri serta lingkungan sesuai dengan kondisi Covid-19 saat ini. Manfaat yang diharapkan dari kegiatan ini adalah mampu meningkatkan kepedulian, kemandirian, kebersihan dan produktifitas di masa pandemi Covid-19. Melalui pendampingan progam ini, pencapaian yang diinginkan adalah perubahan perilaku dan gaya hidup baik bagi mahasiswa, santri, serta masyarakat Desa Malangsuko.

\section{METODE}

Kegiatan KSM-Tematik ini bertempat di Desa Malangsuko, Kecamatan Tumpang, Kabupaten Malang yang dilaksanakan dalam kurun waktu satu bulan lamanya terhitung mulai tanggal 31 Januari sampai tanggal 02 Maret 2021. Program pada KSM-Tematik ini dibagi menjadi 3 tahap yaitu: sosialisasi, penyuluhan serta pendampingan, dan evaluasi. Dalam melaksanakan kegiatan ini perlu adanya kerja sama dengan pihak Pondok Pesantren dan pihak Desa selaku tuan rumah, santri dan masyarakat sekitar sebagai peserta, sehingga program KSM-T ini dapat berjalan dan berkelanjutan. 


\section{HASIL DAN PEMBAHASAN}

Pada kegiatan KSM-Tematik yang merupakan ini merupakan program pengabdian yang dibagi menjadi 3 tahapan, diantaranya: tahap 1 adalah tahap sosialisasi, tahapan 2 adalah penyuluhan serta pendampingan, dan tahap 3 adalah tahap evaluasi. Untuk program pengabdian tahap 1 diawali dengan sosialisasi program kepada pihak Pondok Pesantren dan Pihak Desa tanpa mengumpulkan kerumunan yang artinya sosialisasi dilakukan dengan acara mengunjungi pondok pesantren dan mengunjungi warga di rumahnya masing-masing. Program pengabdian dijelaskan untuk memberikan gambaran secara menyeluruh mengenai program kegiatan oleh tim pengabdi. Pihak pondok pesantren dan pihak Desa sangat antusias dengan program ini. Hasil dari sosialisasi ini adalah pihak pondok pesantren dan pihak Desa dapat membangun interaksi dan kerjasama mengenai program yang akan dijalankan, agar terwujudnya kolaborasi antara pihak pondok pesantren, masyarakat sekitar dengan tim pengabdi.

Kegiatan pengabdian tahap 2 adalah penyuluhan serta pendampingan yang telah dilaksanakan dengan pihak pesantren dan pihak Desa. Pada tanggal yang telah ditetapkannya pelaksanaan kegiatan penyuluhan kami mengerjakan metode dan informasi lebih lanjut mengenai Covid-19. Sehingga pihak pondok dan pihak Desa dapat lebih memahami dan mengerti apa yang harus dilakukan. Harapan dari kegiatan seperti ini, dapat mengarahkan para Santri agar selalu menjaga kesehatan dan tetap mematuhi protokol kesehatan sebagaimana anjuran dari Pemerintah melalui kegiatan sosialisasi Pencegahan Covid-19, pembagian masker dan edukasi penanaman serta pemanfaatan TOGA.

Pembagian masker dilakukan sebelum acara sosialisasi pencegahan Covid-19 dimulai, kemudian pemberian informasi kegiatan edukasi penanaman dan pemanfaatan TOGA dilakukan seminggu sebelum kegiatan. Adapun tanaman TOGA yang digunakan pada saat edukasi penaman serta pemanfaatan TOGA yang meliputi: kunyit, serai, jahe, temulawak, dringu.

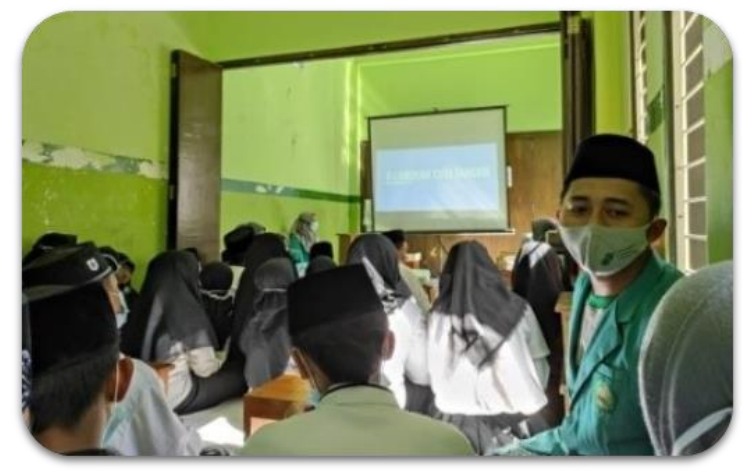

Gambar 1. Sosialisasi Pencegahan Covid-19 kepada para Santri (dok. KSM-T19)

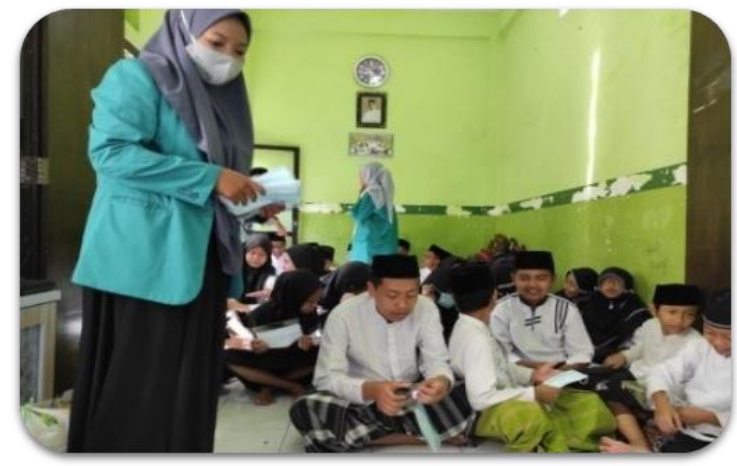

Gambar 2. Pembagian Masker kepada para Santri (dok. KSM-T19) 


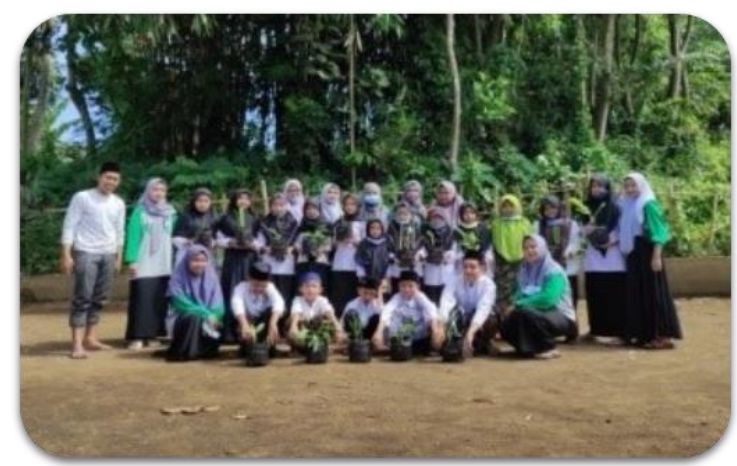

Gambar 3. Penanaman TOGA bersama para Santri (dok.KSM-T19)

Kegiatan pembuatan handsanitizer dengan ibu-ibu kader serta kerjabakti di Musholla dilakukan untuk menumbuhkan kesadaran masyarakat dalam menjaga kesehatan dan kebersihan diri sendiri serta lingkungan. Sekaligus meningkatkan produktfitas masyarakat ditengah pandemi Covid-19.

Mahasiswa mengenalkan bahan-bahan handsanitizer dalam bentuk gel dan cair (spray) bahan-bahan yang digunakan untuk membuat handsanitizer gel meliputi: alcohol dengan kadar 70\%, aloe vera, dan essential oil. Sedangkan bahan handsanitizer cair 9spray) meliputi: alcohol dengan kadar 70\%, baby oil dan essential oil. Yang mana semua bahan tersebut dicampur menjadi bahan yang aman untuk membersihkan tangan dari bakteri, virus, dan kuman. Kegiatan ini merupakan program mahasiswa KSM Tematik untuk membantu pemerintah daerah dalam upaya menghambat perkembangan virus Covid-19 di wilayah Desa Malangsuko Kecamatan Tumpang Kabupaten Malang.

Adapun kerja bakti dilakukan di Musholla Nurul Iman Desa Malangsuko agar masyarakat sekitar tergerak untuk menjaga kebersihan lingkungan sekitar serta menumbuhkan jiwa gotong royong dan meningkatkan kepedulian masyarakat terhadap kebersihan Musholla.

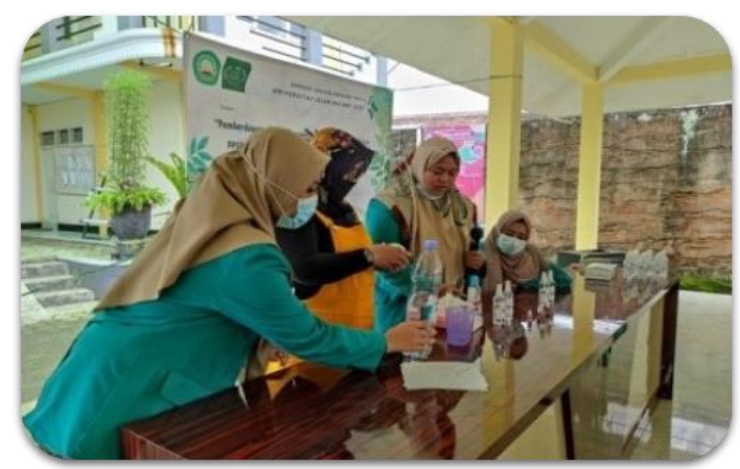

Gambar 4. Pembuatan Handsanitizer bersama Masyarakat (dok.KSM-19) 


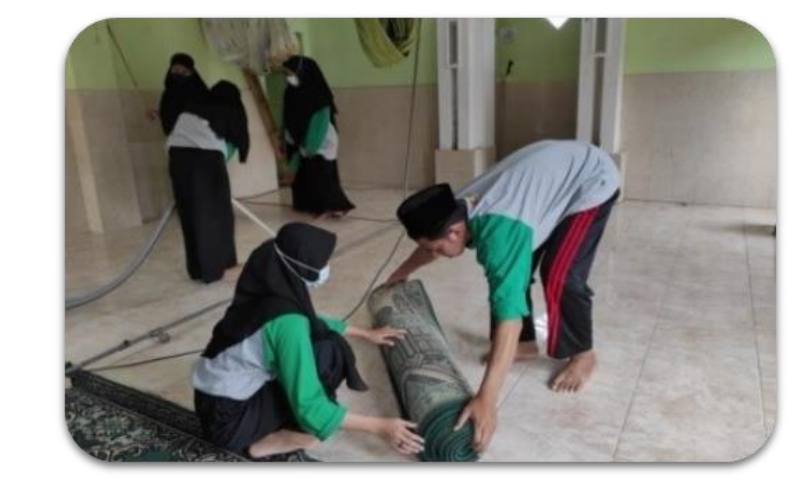

Gambar 5. Kerja bakti membersihkan Mushola (dok.KSM-19)

Tahap ke 3 adalah evaluasi, dari kegiatan mulai dari sosialisasi dan pembuatan handsanitizer dapat bermanfaat dalam mengurangi potensi penularan Covid-19 dimana santri dan warga sekitar tidak hanya berkegiatan di dalam pondok pesantren ataupun di rumah saja, akan tetapi juga melakukan kegiatan diluar pondok pesantren dan rumah yang terkadang memerlukan kontak langsung dengan orang lain. Sedangkan dampak dari kegiatanbercocok tanam tanaman TOGA, dan juga kerja bakti Musholla Nurul Iman adalah dapat diaplikasikannya dengan baik dan benar supaya mampu menjaga kesehatan mandiri dan lingkungan sekitar.

\section{KESIMPULAN}

Dalam kegiatan pengabdian ini dapat ditarik kesimpulan sebagai langkah antisipasi dalam pencegahan Covid-19 terhadap kesehatan ataupun kebersihan lingkungan di Pondok Pesantren dan di lingkungan masyarakat, melalui kegiatan sosialisasi pencegahan Covid-19, penanaman TOGA, pembuatan handsanitizer, serta kerja bakti membersihkan Mushola. Dari semua kegiatan ini bertujuan untuk membantu masyarakat dalam pencegahan penularan Covid-19.

\section{UCAPAN TERIMA KASIH}

Ucapan terima kasih disampaikan kepada LPPM UNISMA; Pemerintahan Desa Malangsuko; Pondok Pesantren di Desa Malangsuko, Koordinator serta masyarakat yang berada disekitar Desa Malangsuko dan seluruh Tim KSM Tematik Unisma Desa Malangsuko 2021.

\section{DAFTAR RUJUKAN}

Bahri, S., \& Arafah, N. (2020). Analisis Manajemen SDM Dalam Mengembangkan Strategi Pembelajaran Di Era New Normal. Journal of Islamic Education, 1(1), 20-40. https://doi.org/10.31538/tijie.v1i1.2

Habibi, A. (2020). Normal Baru Pasca Covid-19. ADALAH Buletin Hukum \& Keadilan, 4(3), 197-202. https://doi.org/10.15408/adalah.v4i1.15809

Hirawan, F. B., \& Verselita, A. A. (2020). Kebijakan Pangan di Masa Pandemi COVID-19. Centre for Strategic and International Studies. https://www.csis.or.id/publications/kebijakan-pangan-di-masa-pandemi-covid-19

Ilpaj, S. M., \& Nurwati, N. (2020). Analisis Pengaruh Tingkat Kematian Akibat Covid-19 Terhadap Kesehatan Mental Masyarakat di Indonesia. Focus: Jurnal Pekerjaan Sosial, 3(1), 16-28. https://doi.org/10.24198/focus.v3i1.28123

Jureid. (2020). Ekonomi Syariah Sebagai Alternatif Kesejahteraan Ekonomi Masyarakat Pada Era Covid-19. Jurnal Kajian Ekonomi Dan Kebijakan Publik, 5(2), 224-236. http://jurnal.pancabudi.ac.id/index.php/jepa/article/view/910 
Pane, M. D. C. (2020). COVID-19 adalah penyakit yang disebabkan oleh virus severe acute respiratory syndrome coronavirus 2 (SARS-CoV-2). COVID-19 dapat menyebabkan gangguan sistem pernapasan, mulai dari gejala yang ringan seperti flu, hingga infeksi paru-paru, seperti pneumonia. Alodokter.Com. https://www.alodokter.com/covid-19

Pratiwi, W. R., Hamdiyah, \& Asnuddin. (2020). Deteksi Dini Masalah Kesehatan Reproduksi Melalui Pos Kesehatan Remaja. Jurnal Inovasi Hasil Pengabdian Masyarakat (JIPEMAS), 3(1), 87-94. https://doi.org/10.33474/jipemas.v3i1.5035

Purnamasari, I., \& Ell Raharyani, A. (2020). Tingkat Pengetahuan Dan Perilaku Masyarakat Kabupaten Wonosobo Tentang Covid -19. Jurnal Ilmiah Kesehatan, 3(1), 33-42. https://ojs.unsiq.ac.id/index.php/jik/article/view/1311

Puspa, I. A. T., Agung, I. G. N. P., \& Mertayasa, I. K. A. (2020). Seni Majejaitan dan Metanding Sebagai Atraksi Wisata di Era New Normal. Pariwisata Budaya: Jurnal Ilmiah Pariwisata Agama Dan Budaya, 18(2), 231-250. https://doi.org/10.25078/pba.v5i2.1798

Safi, I., Candra, A. I., Widodo, S. R., Santoso, A., Heryanto, B., Winarti, E., \& Rahmadi, A. N. (2021). Pembuatan masker dan bilik disinfektan sebagai upaya membantu masyarakat terdampak covid-19. Jurnal Inovasi Hasil Pengabdian Masyarakat (JIPEMAS), 4(1), 36-45. https://doi.org/10.33474/jipemas.v4i1.7524

Siagian, T. H. (2020). Mencari Kelompok Berisiko Tinggi Terinfeksi Virus Corona Dengan Discourse Network Analysis. Jurnal Kebijakan Kesehatan Indonesia, 9(2), 98-106. https://doi.org/10.22146/jkki.55475 